\title{
The Safe Use of Sugammadex “Rescue” after Neostigmine: 2 Case Reports
}

\author{
Joseph F. Answine1,2 \\ ${ }^{1}$ Pinnacle Health Hospitals, Harrisburg, PA, USA \\ ${ }^{2}$ Department of Anesthesiology, Pennsylvania State University Hospital, Hershey, PA, USA \\ Email: janswine@yahoo.com
}

How to cite this paper: Answine, J.F. (2016) The Safe Use of Sugammadex "Rescue" after Neostigmine: 2 Case Reports. Open Journal of Anesthesiology, 6, 125-127. http://dx.doi.org/10.4236/ojanes.2016.69021

Received: August 6, 2016

Accepted: September 6, 2016

Published: September 9, 2016

Copyright (C) 2016 by author and Scientific Research Publishing Inc. This work is licensed under the Creative

Commons Attribution International License (CC BY 4.0).

http://creativecommons.org/licenses/by/4.0/

(c) (†) Open Access

\begin{abstract}
With the introduction of the rocuronium and vecuronium binding agent sugammadex into clinical practice in the United States, its use for reversal of neuromuscular blockade will likely start in some institutions as a "rescue" after failed reversal with neostigmine. However, sugammadex after neostigmine has not been extensively studied. Therefore, there is a question as to its effectiveness when used in this way especially in the airway compromised patients that the anesthesia provider will commonly face in this situation. Furthermore, there is a possibility of hemodynamic compromise. These two case reports demonstrate the safe and effective use of sugammadex after failed reversal with neostigmine.
\end{abstract}

\section{Keywords}

Sugammadex, Neostigmine, Reversal, Airway, Hemodynamics, Rocuronium, Vecuronium, Neuromuscular Blockade, Nicotinic, Weakness, Bradycardia, Train-of-Four

\section{Introduction}

Although not considered the "usual" or "approved" use of sugammadex, it will likely be used quite commonly as a "rescue" for failed or incomplete reversal with neostigmine. Furthermore, the situation and patient population also expectedly will not be optimal or routine. In many cases, the endotracheal tube will have been removed followed by signs of an inadequate airway with airway obstruction and arterial oxygen desaturation. The patients also commonly will have limited reserve whether secondary to age, lung disease, obstructive sleep apnea or significant obesity.

The success and safety of the use of sugammadex after neostigmine have not been studied appropriately. De Menezes in 2012 published a case report about the utilization 
of sugammadex after neostigmine which described a successful recovery but did not delve into the stability of the hemodynamics [1]. Lenz described the utilization of sugammadex after neostigmine in another case report with successful recovery and stable hemodynamics [2]. There have also been studies performed looking at sugammadex in combination with neostigmine for reversal of neuromuscular blockade, but not after the rise in acetylcholine at the receptor site has already occurred due to acetylcholinesterase inhibition [3].

Because of the sparse data, there is a question as to the appropriateness of sugammadex reversal of rocuronium or vecuronium induced neuromuscular blockade after neostigmine reversal. Not only is there a concern of success in completing the reversal, but, also whether there is a potential negative effect of unopposed enhanced acetylcholine exposure at the nicotinic neuromuscular receptor and to a lesser extent at the muscarinic receptor in the heart. Herbstreit in 2010 demonstrated that neostigmine after spontaneous reversal can lead to clinical signs of re-paralysis [4]. It can therefore be assumed that unopposed acetylcholine after neostigmine and then rapid sugammadex reversal could lead to the same findings. Furthermore, it has been noted that sugammadex reversal of rocuronium blockade can lead to rare profound bradycardia which can logically be assumed to be related to unopposed acetylcholine effect at the cardiac muscarinic receptors.

\section{Case Reports}

Two patients are presented here that had surgical procedures at a free standing surgical center, both receiving sugammadex after incomplete reversal with neostigmine. Furthermore, both had diseases or morphologic features consistent with potential airway compromise. The first patient was a 46 year old 92 kilogram male $\left(B M I 36 \mathrm{~kg} / \mathrm{m}^{2}\right)$ for endoscopic sinus surgery. His past medical history was significant for hypertension and obstructive sleep apnea requiring continuous positive airway pressure at night. He was intubated using propofol $200 \mathrm{mg}(2.2 \mathrm{mg} / \mathrm{kg}) \mathrm{IV}$ and rocuronium $50 \mathrm{mg}(0.5 \mathrm{mg} / \mathrm{kg}) \mathrm{IV}$ without difficulty. The procedure lasted approximately 25 minutes, and using qualitative train-of-four (TOF) monitoring, two faint twitches were present. Neostigmine 4 $\mathrm{mg}$ IV and glycopyrrolate $0.8 \mathrm{mg}$ IV were given at that time. Four twitches were present at 7 minutes after reversal and the patient was extubated. Within 3 minutes, obvious airway obstruction and upper extremity weakness were noted with an arterial oxygen saturation in the range of $85 \%$ to $88 \%$ with assisted mask ventilation. Sugammadex 200 $\mathrm{mg}(2.2 \mathrm{mg} / \mathrm{kg})$ was given as a rapid IV bolus with complete resolution of the obstruction, and there were no signs of upper extremity weakness within two minutes after administration. The arterial oxygen saturation was maintained at $>94 \%$ with a nasal cannula at four $1 / \mathrm{min}$. Hemodynamics were overall maintained with the heart rate decreasing from 93 beats/minutes prior to sugammadex to 79 beats/minute after, and the non-invasive blood pressure was 144/96 $\mathrm{mmHg}$ prior and 135/84 $\mathrm{mmHg}$ after. The slight changes in hemodynamics were assumed to be related to a decrease in patient stress with improved ventilation. 
The second patient was a 38 year old 102 kilogram male (BMI $\left.41 \mathrm{~kg} / \mathrm{m}^{2}\right)$ with a medical history significant for diabetes type 2 and hypertension. His AM blood glucose was $134 \mathrm{mg} / \mathrm{dl}$ and blood pressure was 128/71 mmHg. He underwent right knee arthroscopy with a failed laryngeal mask airway placement and urgent endotracheal intubation with propofol $200 \mathrm{mg}(2.0 \mathrm{mg} / \mathrm{kg}) \mathrm{IV}$ and rocuronium $50 \mathrm{mg}(0.5 \mathrm{mg} / \mathrm{kg}) \mathrm{IV}$. The surgical procedure lasted 32 minutes. Neostigmine $3 \mathrm{mg}$ IV and glycopyrrolate $0.6 \mathrm{mg}$ IV were given with three twitches present using qualitative TOF monitoring. The patient was extubated 5 minutes after reversal with four twitches and a sustained tetanus present as well as a respiratory tidal volume greater than $800 \mathrm{ml}$. The patient began showing signs of airway obstruction with quick desaturation to $78 \%$ and tachypnea at 30 breaths/ minute. Sugammadex $200 \mathrm{mg}(1.96 \mathrm{mg} / \mathrm{kg}) \mathrm{IV}$ was given followed by a saline push with relief of obstruction within 1.5 minutes after administration. There was no significant change in heart rate when comparing prior and after sugammadex administration (103 beats/min and 98 beats/min respectively), and the non-invasive blood pressure decreased from 156/101 $\mathrm{mmHg}$ to $139 / 92 \mathrm{mmHg}$. Arterial oxygen saturation rose to $97 \%$ with a face mask in place with no postoperative complications noted.

Both patients were discharged from the facility within the usual timeframe without signs of continued airway compromise and stable hemodynamics. The first patient recalled a feeling of being "unable to breathe" which resolved prior to leaving the operating room, and both only described, via a phone call on post-operative day 1, a mild sore throat but no other anesthesia related concerns.

\section{Conclusion}

These case reports demonstrate the safe and successful use of sugammadex after neostigmine. Although more extensive studies should be done, this brings to light another situation where sugammadex could lead to improved patient safety and outcomes.

\section{References}

[1] De Menezes, C.C., Peceguini, L.A., Silva, E.D. and Simões, C.M. (2012) Use of Sugammadex after Neostigmine Incomplete Reversal of Rocuronium-Induced Neuromuscular Blockade. Revista Brasileira de Anestesiologia, 62, 543-547. http://dx.doi.org/10.1016/S0034-7094(12)70153-8

[2] Lenz, A., Hill, G. and White, P. (2007) Emergency Use of Sugammadex after Failure of Standard Reversal Drugs. Anesthesia \& Analgesia, 104, 585-586. http://dx.doi.org/10.1213/01.ane.0000253231.76654.45

[3] Kakinuma, A., Nagatani, H., Yasuda, A., Yoshimura, T., Sawai, J., et al. (2013) Combined Use of Sugammadex and Neostigmine for the Reversal of Rocuronium-Induced Profound Neuromuscular Blockade. Journal of Anesthesia \& Clinical Research, 4, 337. http://dx.doi.org/10.4172/2155-6148.1000337

[4] Herbstreit, F., Zigrahn, D., Ochterbeck, C., Peters, J. and Eikermann, M. (2010) Neostigmine/Glycopyrrolate Administered after Recovery from Neuromuscular Block Increases Upper Airway Collapsibility by Decreasing Genioglossus Muscle Activity in Response to Negative Pharyngeal Pressure. Anesthesiology, 113, 1280-1288.

http://dx.doi.org/10.1097/ALN.0b013e3181f70f3d 
Submit or recommend next manuscript to SCIRP and we will provide best service for you:

Accepting pre-submission inquiries through Email, Facebook, LinkedIn, Twitter, etc. A wide selection of journals (inclusive of 9 subjects, more than 200 journals)

Providing 24-hour high-quality service

User-friendly online submission system

Fair and swift peer-review system

Efficient typesetting and proofreading procedure

Display of the result of downloads and visits, as well as the number of cited articles

Maximum dissemination of your research work

Submit your manuscript at: http://papersubmission.scirp.org/ 